\section{İşletme İçinde Oluşturulan Maddi Olmayan Duran Varlıkların Türkiye Muhasebe/Finansal Raporlama Standartlarına Göre Raporlanması}

\section{Bilal Gerekan ${ }^{\mathrm{a}}$}

Öz: Bu çalışmanın amacı, işletme içinde oluşturulan maddi olmayan duran varlıkların Türkiye Muhasebe/Finansal Raporlama Standartları kapsamındaki muhasebeleştirme ilkelerini ortaya koymaktır. Maddi olmayan duran varlıklarla ilgili çok sayıda çalışma olmasına rağmen işletme içinde oluşturulan maddi olmayan duran varlıklarla ilgili çalışma sayısı oldukça sınırıdır. Bu çalışma literatürdeki bu boşluğu doldurmaya yönelik ele alınmıştır. Çalışmada, TMS: 38 Maddi Olmayan Duran Varlıklar Standardı esas alınarak muhasebeleştirme ilkeleri, uygulamalar yardımıyla gösterilmiştir. Muhasebe kayıtlarına esas alınan hesaplar için Kamu Gözetimi Muhasebe ve Denetim Standartları Kurumu tarafından yayımlanan Taslak Hesap Planından faydalanılmıştır. Uygulamalar, "fiili maliyet yöntemi" ve "önceden saptanmıs maliyet yöntemlerine" göre ayrı ayrı ele alınarak çözümlenmiştir. Taslak Hesap Planındaki hesaplar ile Tekdüzen Hesap Planındaki hesaplar arasındaki farkllıklar incelenmiş ve hangi maliyet yöntemi için muhasebeleștirmede nelere dikkat edilmesi gerektiği değerlendirilmiştir. İ̧̧letme içinde oluş̧urulan maddi olmayan duran varlıklar için araştırma ve gelişstirme safhalarındaki masrafların raporlamasında bir takım farklılıklar söz konusudur. Fiili maliyet yöntemi yerine önceden saptanmıs maliyet yöntemlerinin kullanılması durumunda dönem sonunda fark hesaplarının kullanılması gerekmektedir. Patent masrafları da dâhil olmak üzere geliş̧tirme sürecinde katlanılan masrafların hangi hesaba yazılması gerektiği taslak hesap planında netlik kazanmıştır Bununla birlikte, literatürde yer alan söz konusu masrafların nereye yazılması gerektiği sorunu da ortadan kalkmıştır.

\section{Reporting the Internally Developed Intangible Assets According to Turkish Accounting/Financial Reporting Standards}

Abstract: The aim of this study is to reveal accounting principles internally developed intangible assets in the scope of Turkey Accounting/Financial Reporting Standards. Although there are many studies on intangible assets, the number of studies on internally developed intangible assets is quite limited. This study has been discussed to fill this gap in the literature. In the study, accounting principles are shown with the applications based on TAS: 38 Intangible Assets Standard. The draft chart of accounts published by the Public Oversight Accounting and Auditing Standards Authority was used for the accounts that on the accounting records. The practices were handled and resolved separately according to the "actual cost method" and "predetermined cost methods". The differences between the accounts in the draft chart of accounts and those in the uniform chart of accounts have been examined. It has been evaluated that what should be considered in accounting for which cost method. There are some differences in the reporting of expenses in research and development phases for internally developed intangible assets. If predetermined cost methods are used instead of the actual cost method, it is necessary to use difference accounts at the end of the period. It is clear in the draft chart of accounts to which account the costs incurred in the development process, including the patent costs, should be written. However, the problem of where to write the costs in question has also disappeared.
Anahtar Sözcükler: İşletme İçinde Oluşturulan Maddi Olmayan Duran Varlıklar, TMS/TFRS

JEL: M40, M41

$\begin{array}{ll}\text { Geliş } & : \text { 17 Eylül } 2020 \\ \text { Düzeltme } & : 28 \text { Ekim } 2020 \\ \text { Kabul } & : 18 \text { Kasım 2020 } \\ & \\ \text { Tür } & : \text { Kavramsal }\end{array}$

Keywords: Internally Developed Intangible Assets, TASs/TFRSs

JEL: M40, M41

Received : 17 September 2020

Revised : 28 October 2020

Accepted : 18 November 2020

Type : Conceptual

a Assoc. Prof., PhD., Karadeniz Technical University, Faculty of Economics and Administrative Sciences, Department of Business Administration, Trabzon, Turkiye, gerekan@ktu.edu.tr (ORCID ID: 0000-0001-8558-7928) 


\section{Giriş}

Finansal raporlama açısından maddi olmayan duran varlıkların önemi her geçen gün artmaktadır. Açıklanan rakamlar yanında açıklanmayan/açıklanamayan değerler de içerdiğinden bu önemin gittikçe aratacağı beklenmektedir. Günümüzde işletmeler için çeşitli finansal formüller yardımıyla hesaplanan marka değeri, firma değeri gibi verilerin finansal raporlara ne şekilde yansıtılabileceği bu konuyla ilgili tartışılan en önemli başlıklardan biridir.

Brand Finance tarafından yayımlanan GIFT-2019 Raporu'nda çeşitli hesaplamalarla ulaşılan global düzeyde faaliyet gösteren kuruluşların maddi olmayan değerlerine yer verilmiştir. Bu raporun ilk sırasında Microsoft (904 milyon \$), ikinci sırasında Amazon (839 milyon \$) ve üçüncü sırasında ise Apple (675 milyon \$) yer almaktadır (Brand Finance, 2019: 18). Bu rakamlar, maddi olmayan değerlerin global düzeyde ne seviyelere ulaştığını anlamak bakımından dikkat çekicidir. Maddi olmayan değerlerle ilgili finansal raporlamada sunum ve değerlemenin ne derece önemli olduğunu da ortaya koymaktadır.

Sunum ve değerleme bakımından maddi olmayan duran varlıklar, benimsenen finansal raporlama çerçevesi ve mevzuattan önemli düzeyde etkilenen bir hesap grubudur. Ülkemizde, Muhasebe Sistemi Uygulama Genel Tebliği, Türkiye Muhasebe/Finansal Raporlama Standartları (TMS/TFRS) ve konuyla ilgili mevzuattaki çeşitli farklılıklar göze çarpmaktadır. TMS 38: Maddi Olmayan Duran Varlıklar Standardında bu gruba ait temel kalemler; bilgisayar yazılımı, patentler, telif hakları, sinema filmleri, müşteri listeleri, ipotek hizmeti sunma hakları, balıkçılık lisansları, ithalat kotaları, isim hakları, müşteri ve tedarikçi ilişkileri, müşteri sadakati, pazar payı ve pazarlama hakları olarak sayılmıştır (Md. 9). Bu varlıklar, işletme dışından sağlanabildiği gibi işletme içinde de oluşturulabilir niteliktedir.

Maddi olmayan duran varlıklarla ilgili literatürde çok sayıda çalışma olmasına rağmen işletme içinden sağlanan maddi olmayan duran varlıklara yönelik çalışma sayısı oldukça sınırlıdır. Bu çalışmada, işletme içinden sağlanan maddi olmayan duran varlıkların TMS/TFRS kapsamındaki raporlama ilkeleri incelenmiştir. Çalışmayı, önceki çalışmalardan ayıran temel nokta budur. İşlemlere ilişkin yapılan muhasebe kayıtlarında, Kamu Gözetimi Muhasebe ve Denetim Standartları Kurumu (KGK) tarafından yayımlanan Taslak Hesap Planındaki hesaplardan yararlanılmıştır. Konuya ilişkin verilen uygulamalarda "fiili maliyet yöntemi" ile "önceden saptanmış maliyet yöntemleri" ayrı ayrı ele alınarak farklılaşan noktalar açıklanmıştır. Bu kapsamda, ilk olarak konuyla ilgili teorik açıklamalar yapılmış, daha sonra işletme içinde oluşturulan maddi olmayan duran varlıklarla ilgili uygulamalara yer verilmiştir. Son olarak da temel muhasebeleştirme prensipleri yanında fiili maliyet yöntemi ile önceden saptanmış maliyet yöntemlerinin ayrıştığı noktalar değerlendirilmiştir.

\section{2. İşletme İçinde Oluşturulan Maddi OImayan Duran Varlıklar}

Duran varlıklar sınıfı içinde maddi olmayan duran varlıklar hesap grubu gerek hesap kalemlerinin niteliği gerekse de çeşitli düzenlemeler karşısındaki durumu bakımından oldukça kapsamlıdır. İşletme dışından satın alınabildiği gibi işletme içinde de oluşturulabilen maddi olmayan duran varlıkların finansal tablolara aktarılma ilkelerine TMS 38: Maddi Olmayan Duran Varlıklar Standardında yer verilmiştir. Söz konusu standartta muhasebeleştirme için gerekli ölçütlerin sağlanıp sağlanamadığı, işletme içi oluşturulan maddi olmayan duran varlığın oluşumunun "araştırma" ve "geliştirme" safhalarına göre belirleneceği belirtilmiştir (Md. 52). Araştırma safhasındaki harcamaların maddi olmayan duran varlık olarak değil gider olarak muhasebeleştirileceği açıklanmıştır (Md. 54). Zira üzerinde çalışılan bir projenin araştırma safhasında, gelecekte kendisinden ekonomik yarar sağlanacak bir maddi olmayan duran varlığın oluşacağı kesin değildir (Md. 55). Geliştirme safhası daha ileri bir aşama olduğundan işletme, oluşturulan maddi olmayan duran varlıkla ilgili gelecekteki muhtemel ekonomik yararları belirleyebilme imkânına daha fazla sahiptir (Md. 58). Bu nedenle standartta, geliştirme safhasındaki harcamaların, belirli şartları taşımaları halinde maddi olmayan duran varlık olarak muhasebeleştirileceği belirtilmiştir (Md. 57). Buna karşılık; işletme içi oluşturulan markalar, ticari başlıklar, yayın hakları, müşteri listeleri ve benzer nitelikteki kalemlerin maddi olmayan duran varlık olarak muhasebeleştirilmeyeceği de ayrıca açıklanmıştır (Md. 63). 
İşletme içi oluşturulan maddi olmayan duran varlıkların maliyetinin hangi unsurları kapsadığına da ilgili standartta yer verilmiştir. Buna göre maliyet; yönetim tarafından belirlenen şekilde çalışabilmesi için ilgili varlığın oluşturulması, üretilmesi ve hazırlanmasında katlanılan ve varlıkla doğrudan ilişkilendirilebilen harcamaların tümünü içermektedir (Md. 66). Ayrıca proje sürecinin başlangııında gider olarak muhasebeleştirilen harcamalar, daha sonraki aşamalarda maddi olmayan duran varlığın maliyetinin bir parçası olarak muhasebeleştirilememektedir (Md. 71).

Standartta yer alan açıklamalar ışığında KGK tarafından açıklanan Taslak Hesap Planı'nda işletme içi oluşturulan bir maddi olmayan duran varlı̆ın aşama aşama hangi hesaplarda izlenmesi gerektiği açıklanmıştır. Bu işlemlerle ilgili Taslak Hesap Planında yer alan hesaplar aşağıdaki gibidir:

\section{3 işletme Içinde Oluşturulmuş Maddi Olmayan Duran Varlıklar Hesabı}

\section{Geliştirme Maliyetleri Hesabı}

\section{Araştırma ve Geliştirme Giderleri Hesabı}

\section{Yapılmakta Olan Maddi Olmayan Duran Varlık Yatırım Maliyetleri Hesabı}

\section{Araştırma Giderleri Hesabı}

\section{Araştırma Giderleri Yansıtma Hesabı}

\section{Araştırma Gider Farkları Hesabı}

753 Geliştirme Giderleri Hesabı

\section{Geliştirme Giderleri Yansıtma Hesabı}

\section{Geliştirme Gider Farkları Hesabı}

Tekdüzen Hesap Planı ile karşılaştırıldığında maliyet hesapları içinde "araştırma" ve "geliştirme" safhalarına ait maliyetlerin Taslak Hesap Planında ayrı ayrı oluşturulduğu göze çarpmaktadır. Bunun dışında, maliyet hesapları arasında yapılmakta olan maddi olmayan duran varlıklar için yatırım maliyetlerinin izlendiği bir hesabın Taslak Hesap Planında varlığı dikkati çekmektedir. Gelir tablosu hesabı bakımından 630 Araştırma ve Geliştirme Giderleri Hesabı iki hesap planında da mevcuttur. Ayrıca bilanço hesapları açısından bakıldığında 264 Geliştirme Maliyetleri Hesabı, Tekdüzen Hesap Planından farklı olarak Taslak Hesap Planında, TMS/TFRS'deki yaklaşıma daha uygun olarak geliştirilmiş bir hesap olarak karşımıza çıkmaktadır. Geliştirme safhasında bulunan maddi olmayan duran varlıklardan kullanıma hazır olanların izlendiği 263 İşletme İçinde Oluşturulmuş Maddi Olmayan Duran Varlıklar Hesabı ise Tekdüzen Hesap Planı ile Taslak Hesap Planı'nın en önemli farklılıklarından biridir. Taslak Hesap Planı'nda yer alan bu hesap, işletme içinde oluşturulmuş olan maddi olmayan duran varlıkların hangi hesapta izlenmesi gerektiği sorununu da ortadan kaldırmaktadır.

Maddi olmayan duran varlıklara ilişkin mevzuat incelendiğinde; aktifleştirme, amortisman, teşvik gibi çeşitli açılardan bu varlıklara ait kalemlerle ilgili farklı düzenlemelerin olduğu görülmektedir. Sadece AR-GE harcamalarıyla ilgili bile çok sayıda düzenlemeye rastlamak mümkündür. Bu açıdan bakıldığında, 5746 Sayılı Araştırma, Geliştirme ve Tasarım Faaliyetlerinin Desteklenmesi Hakkında Kanun'a göre; AR-GE, yenilik ve tasarım harcamalarının 213 Sayılı Vergi Usul Kanunu'na göre aktifleştirilmek suretiyle amortisman yoluyla itfa edileceği belirtilmiştir. Herhangi bir iktisadi kıymet oluşmaması halinde ise doğrudan gider yazılacağı açıklanmıştır (Md. 3/1). Muhasebeleştirme açısından önemli olan bu husus, mevzuatla standartlar arasında bir takım farklılıklara neden olabilmektedir. Nitekim, 5746 Sayılı Kanun'a göre yapılan harcamaların araştırma ve geliştirme safhasına bakılmadan aktifleştirilmek suretiyle amortisman yoluyla itfa edileceği, buna karşılık TMS 38'e göre ise araştırma safhasındaki harcamaların gider yazılacağı, geliştirme safhasındaki harcamaların da aktifleştirilebileceği öngörülmektedir. Bu farklııı, standartlar kapsamında kayıt yapılması halinde ortaya çıkacak vergi etkisinin hesaplanması ve raporlanmasını gerekli kılmaktadır.

Iş̧letme içinde oluşturulan maddi olmayan duran varlıklarla ilgili bir diğer önemli konu da yürütülen AR-GE faaliyetlerinin başarıyla sonuçlanması halinde geliştirilen varlığa/sürece ilişkin alınacak patent 
maliyetlerinin nasıl muhasebeleştirilmesi gerektiğidir. Zira Tekdüzen Hesap Planı açısından bakıldı̆̆ında bunun için iki alternatif söz konusudur. Birincisi, 263 Araştırma ve Geliştirme Giderleri Hesabı ikincisi ise 260 Haklar Hesabı'dır. Birinci alternatifte AR-GE faaliyetleriyle ilgili maliyetler yanında katlanılan patent masrafları da 263 Araştırma ve Geliştirme Giderleri Hesabı'na yazılmaktadır (Deran vd., 2017; Fidancı, 2017). İkinci alternatifte ise 263 Araştırma ve Geliştirme Giderleri Hesabı'nda izlenen maliyetler bu hesaptan düşülerek patent masraflarıyla birlikte 260 Haklar Hesabı'na aktarılmaktadır (Şeker, 2009; Bozdemir, 2018). Bu alternatifleri önemli kılan temel neden, iki hesaptaki itfa sürelerinin farklı şekillerde açıklanmış olmasıdır. Tekdüzen Hesap Planında 260 Haklar Hesabı için itfa payının, yararlanma süresi belli ise bu süre içinde, belli değilse 5 yıllık sürede eşit taksitlerle ayrılacağı belirtilmiştir. Buna karşılık, aynı hesap planında 263 Araştırma ve Geliştirme Giderleri Hesabı'nda yer alan tutarların 5 yıl içinde eşit taksitlerle itfa edilerek yok edileceği açıklanmıştır. Dolayısıyla, 260 Haklar Hesabı içerisinde açıklanan "yararlanma süresi" kriteri iki hesabın itfasında farklııklara yol açabilmektedir. Bu da alternatiflerin oluşmasına yol açmıştır. Taslak Hesap Planında ise konuyla ilgili muhasebe ve finansal raporlama standartlarının referans alındığı bilinmektedir. Bununla ilgili TMS 38' de maddi olmayan duran varlıklar "yararlı ömürleri" açısından sınırlı ve sınırsız olmak üzere iki sınıfa ayrılmıştır. Sınırlı yararlı ömre sahip maddi olmayan duran varlıkların itfaya tabi olduğu ancak, sınırsız yararı ömre sahip olanların ise itfaya tabi olmadığı açıklanmıştır (Md. 89). Bu kapsamda, Taslak Hesap Planı esas alınarak yapılacak raporlamada, yürütülen faaliyetlerle ilgili katlanılan maliyetler ve süreç sonunda ortaya çıkan patent masraflarının 263 íşletme İçinde Oluşturulmuş Maddi Olmayan Duran Varlıklar Hesabı'nda izlenmesi amortisman konusunda bir farklılığa neden olmamaktadır. Bu yolla söz konusu maddi olmayan duran varlığa ilişkin tüm maliyet bilgilerinin tek bir hesapta toplanmasına imkân sağlanmış olmaktadır.

\section{3. İsletme İçinde Oluşturulan Maddi Olmayan Duran Varlıkların Muhasebeleştirilmesi}

İ̧̧letme içinde oluşturulan maddi olmayan duran varlıkların muhasebeleştirilmesine ilişkin Taslak Hesap Planında açıklanan bazı hesaplarda "fiili maliyet yöntemi" ve "önceden saptanmış maliyet yöntemlerine" göre kayıtlarla ilgili işleyiş kuralları açıklanmışırı. Maliyet yöntemlerine göre yapılacak kayıtlar arasındaki farkı ortaya koymak için aşağıda iki yönteme göre ayrı ayrı uygulama yapılmış ve çözümlerine ayrıntılı olarak yer verilmiştir.

Örnek: Kimya sektöründe faaliyette bulunan "E" İşletmesi, çeşitli amaçlarla AR-GE faaliyetleri yürütmektedir. 2020 yılında çeşidine göre katlandığı; ilk madde malzeme, personel, dışarıdan sağlanan fayda ve hizmet, çeşitli giderler ve vergi resim ve harçların toplam tutarı araştırma faaliyetleri için 150.000 ,- TL, geliştirme faaliyetleri için ise 200.000,- TL'dir. Dönem sonu itibariyle AR-GE faaliyetleri başarılı bir şekilde sonuçlandırılmış olup, yürütülen geliştirme faaliyetleri sonucunda yeni bir varlık geliştirilmesi ve işletme içinde oluşturulan bu varlığın işletmenin marka değerine olumlu yönde katkı sağlayacağı beklenmektedir.

Çözüm: “E” İşletmesi'nin 2020 yılına ait araştırma faaliyetleri kapsamındaki 150.000,- TL'lik gideri 750 Araştırma Giderleri Hesabı'nda, 200.000,- TL tutarındaki geliştirme faaliyetleri kapsamındaki gideri ise 753 Geliştirme Giderleri Hesabı'nda izlenecektir. Bu amaçla yapılması gereken kayıt aşağıdaki gibi olacaktır:

\begin{tabular}{|c|c|r|r|r|r|}
\hline 750 Araştırma Giderleri Hesabı & 150.000 & & & & \\
\hline 753 Geliştirme Giderleri Hesabı & 200.000 &,- & & \\
\hline ilgili Varlık/Kaynak Hesapları & & & 350.000 & ,- \\
\hline & & & & & \\
\hline
\end{tabular}

Taslak Hesap Planında işletme içi oluşturulan maddi olmayan duran varlıklar için 750 Araştırma Giderleri Hesabı ve 753 Geliştirme Giderleri Hesabı'nda biriken tutarların yansıtma hesapları vasıtasıyla 707 Yapılmakta Olan Maddi Olmayan Duran Varlık Yatırım Hesabı'na aktarılabileceği belirtilmektedir. Bu aktarım için yapılması gereken kayıt aşağıdaki gibi olacaktır: 


\begin{tabular}{|c|c|r|r|r|}
\hline $\begin{array}{c}\text { 707 Yapılmakta Olan Maddi Olmayan Duran } \\
\text { Varlık Yatırım Maliyetleri H. }\end{array}$ & 350.000 &,- & & \\
\hline 751 Araştırma Giderleri Yansıtma H. & & & 150.000 & ,- \\
\hline 754 Geliştirme Giderleri Yansıtma H. & & & 200.000 & ,- \\
\hline
\end{tabular}

Araştırma safhasıyla ilgili olan ve dönem sonunda aktifleştirilemeyen harcamalar 707 Yapılmakta Olan Maddi Olmayan Duran Varlık Yatırım Hesabı'ndan düşülerek 630 Araştırma ve Geliştirme Giderleri Hesabı'na aktarılır. Buna karşılık, geliştirme sürecinin sonunda aktifleştirilebilen harcamalar ise 707 Yapılmakta Olan Maddi Olmayan Duran Varlık Yatırım Hesabı'ndan düşülerek 264 Geliştirme Maliyetleri Hesabı'na aktarılır. Bu amaçla yapılacak kayıt da aşağıdaki gibi olur:

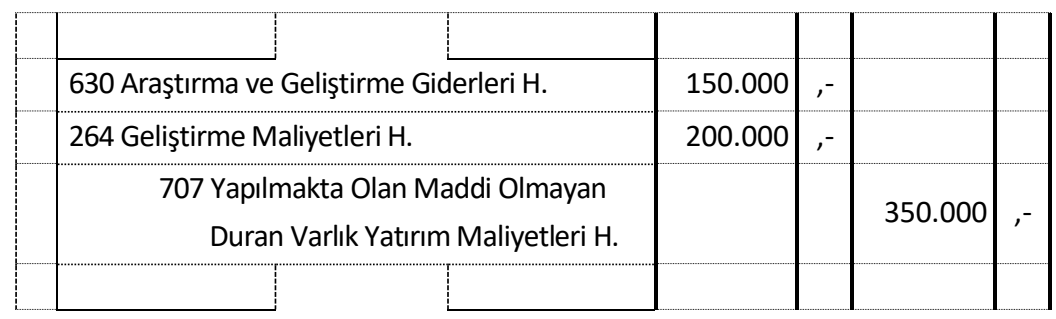

Geliştirme sürecinin sonunda maddi olmayan duran varlıklardan kullanıma hazır hale gelenlere ait tutarlar ise 264 Geliştirme Maliyetleri Hesabı'ndan düşülerek 263 İşletme İçinde Oluşturulmuş Maddi Olmayan Duran Varlıklar Hesabı'na aktarılır. Bu amaçla da aşağıdaki gibi kayıt yapılır:

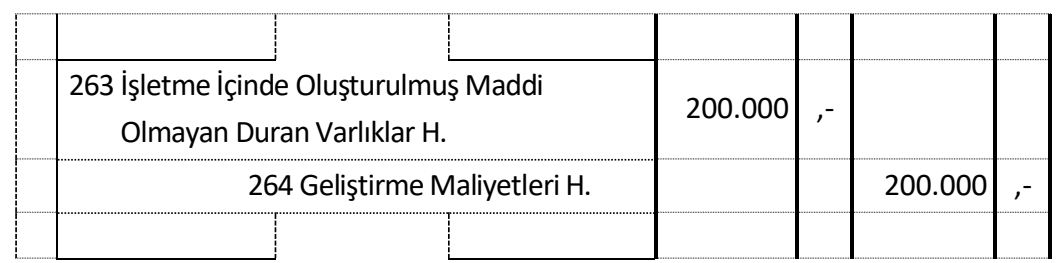

$\mathrm{Bu}$ işlemlere ilişkin yapılan kayıtlarda mevzuat ile TMS/TFRS arasındaki benimsenen kayıt prensiplerinden kaynaklanan farklılığa da kısaca değinilmelidir ${ }^{1}$. Zira bu örnekte 2020 yılı için yapılmış olan toplam AR-GE harcaması 350.000,- TL olarak gerçekleşmiştir. 5746 Sayılı Kanun'da ise bu tutarın tamamının aktifleştirilmesi ve yıllar itibariyle amortisman yoluyla itfa edilmesi gerektiği belirtilmektedir. Dolayısıyla mevzuat kapsamında, bu işlemlerle ilgili beyannameye etki edecek gider tutarı 2020 yılı için 350.000,- TL / 5 yıl = 70.000,- TL/yıl'dır. Oysa TMS/TFRS esas alınarak yapılacak kayıtlara göre 150.000,- TL'si araştırma gideri, 40.000,- $\mathrm{TL}^{\prime} \mathrm{si}^{2}$ ise geliştirme giderinin amortismanı olacak şekilde toplam 190.000,- TL'lik gider bu yılın matrahına etki etmektedir. Aradaki fark; $190.000-70.000=120.000,-$ TL'dir. Bunun anlamı, mevzuata göre yapılacak kayıtlarda $120.000,-$ TL tutarındaki rakamın gider olarak yazılamamasıdır. Bu farkın kurumlar vergisi oranıyla çarpılması sonucunda; $120.000 \times \% 20=24.000$,- TL'lik bir geçici vergi farkının oluştuğu tespit edilmektedir. Bu kapsamda, standartlara göre yapılacak raporlamada oluşan 24.000,- TL'lik indirilebilir geçici vergi farkının da kayıtlara aktarılması unutulmamalıdır.

Dönem sonunda ise maliyet hesabı, yansıtma hesabı ile karşııılı olarak kapatılmalıdır. Bu amaçla yapılması gereken kayıt da aşağıdaki gibi olur:

\begin{tabular}{|c|c|r|r|r|r|}
\hline $\mathbf{3 1 . 1 2 . 2 0 2 0}$ & & & & \\
\hline 751 Araştırma Giderleri Yansitma H. & 150.000 &,- & & \\
\hline 754 Gelisstirme Giderleri Yansıtma H. & 200.000 &,- & & \\
\hline 750 Araştırma Giderleri H. & & & 150.000 &,- \\
\hline 753 Geliştirme Giderleri H. & & & 200.000 & ,- \\
\hline & & & & & \\
\hline
\end{tabular}


Bu kayıtlardan sonra, 263 İşletme İçinde Oluşturulmuş Maddi Olmayan Duran Varlıklar Hesabı'nda izlenen söz konusu maddi olmayan duran varlık için itfa süreci başlayacaktır. Bu süreçte hesaplanan itfa payı; ilgili varlık üretim maliyetinin bir unsuru olarak kullanılıyorsa 730 Genel Üretim Giderleri Hesabı'nda, üretim maliyetinin bir unsuru olarak kullanılmıyorsa 630 Araştırma ve Geliştirme Giderleri Hesabı'na aktarılmak üzere 753 Geliştirme Giderleri Hesabı'nda izlenecektir.

Örnek: Petrokimya sektöründe faaliyette bulunan "E" İ̧̧letmesi, çeşitli amaçlarla ar-ge faaliyetleri yürütmektedir. 01.01.2020 tarihinde yıllık olarak katlanacağı harcamalar toplamının araştırma faaliyetleri için 240.000,- TL, geliştirme faaliyetleri için ise 350.000,- TL olacağı tahmin edilmektedir. Dönem sonu itibariyle AR-GE faaliyetleri başarııı bir şekilde sonuçlandırılmış olup, yürütülen geliştirme faaliyetleri sonucunda yeni bir varlık geliştirilmesi ve işletme içinde oluşturulan bu varlığın işletmenin marka değerine olumlu yönde katkı sağlayacağı beklenmektedir.

a) Dönem sonunda yapılan incelemeler kapsamında "E" iş̧letmesi'nin yıllık harcamaları toplamının araştırma faaliyetleri için 250.000 ,- TL, geliştirme faaliyetleri için ise 400.000 ,- TL olduğu tespit edilmiştir.

b) Dönem sonunda yapılan incelemeler kapsamında "E" İşletmesi'nin yıllık harcamaları toplamının araştırma faaliyetleri için 200.000 ,- TL, geliştirme faaliyetleri için ise 320.000 ,- TL olduğu tespit edilmiştir.

Çözüm: "E" İşletmesi tarafından 2020 yılına ilişkin dönem başında tahmin edilen araştırma ve geliştirme faaliyetlerine ilişkin maliyetler; 707 Yapılmakta Olan Maddi Olmayan Duran Varlık Yatırım Hesabı'nın borcunda, 751 Araştırma Giderleri Yansıtma Hesabı ve 754 Geliştirme Giderleri Yansıtma Hesabı'yla karşıııklı olarak izlenecektir. Bu amaçla yapılması gereken kayıt aşağıdaki gibi olacaktır:

\begin{tabular}{|c|c|r|r|r|}
\hline 01.01 .2020 & & & \\
\hline $\begin{array}{c}\text { 707 Yapılmakta Olan Maddi Olmayan Duran } \\
\text { Varlık Yatırım Maliyetleri H. }\end{array}$ & 590.000 &,- & & \\
\hline 751 Araştırma Giderleri Yansıtma H. & & & 240.000 & ,- \\
\hline 754 Geliştirme Giderleri Yansıtma H. & & & 350.000 &,- \\
\hline & & & & \\
\hline
\end{tabular}

a) Dönem sonunda fiili olarak gerçekleşen harcamaların araştırma faaliyetleri için 250.000 ,- TL ve geliştirme faaliyetleri için ise 400.000 ,- TL olarak gerçekleştiği tespit edilmiştir. Dolayısıyla, dönem içinde gerçekleşen harcamalar nedeniyle ilgili varlık ve kaynak hesaplarına karşılık 750 Araştırma Giderleri Hesabı 250.000,- TL ve 753 Geliştirme Giderleri Hesabı 400.000,- TL borçlandırılmıştır. Bu kapsamda, 750 Araştırma Giderleri Hesabı ve 753 Geliştirme Giderleri Hesabı'nın dönem sonundaki görünümü aşağıdaki gibidir:
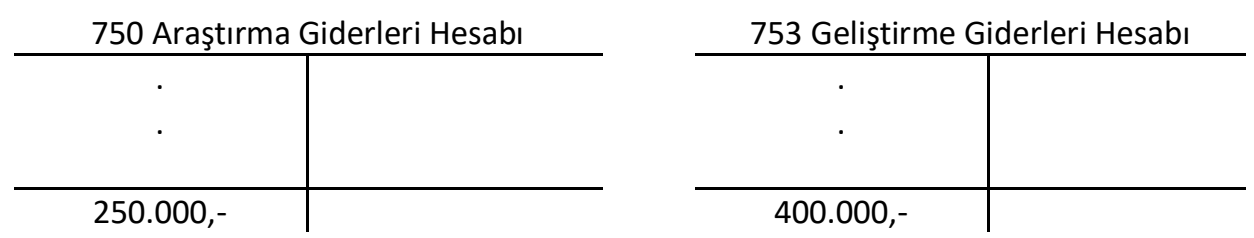

Dönem sonunda tespit edilen fiili rakam, dönem başında tahmin edilen rakamdan araştırma giderleri için 10.000,- TL, geliştirme giderleri için ise 50.000,- TL fazladır. Bu kapsamda, hem araştırma hem de geliştirme giderleri için olumsuz bir farkla karşılaşılmıştır. Bu olumsuz fark, araştırma giderleri için 752 Araştırma Gider Farkları Hesabı'nın, geliştirme giderleri için de 755 Geliştirme Gider Farkları Hesabı'nın borcunda izlenmektedir. Bu hesaplarda izlenen olumsuz fark daha sonra 707 Yapılmakta Olan Maddi Olmayan 
Duran Varlık Yatırım Hesabı'nın borcuna aktarılmalıdır. Bununla ilgili yapılması gereken kayıtlar aşağıdaki gibi olacaktır:

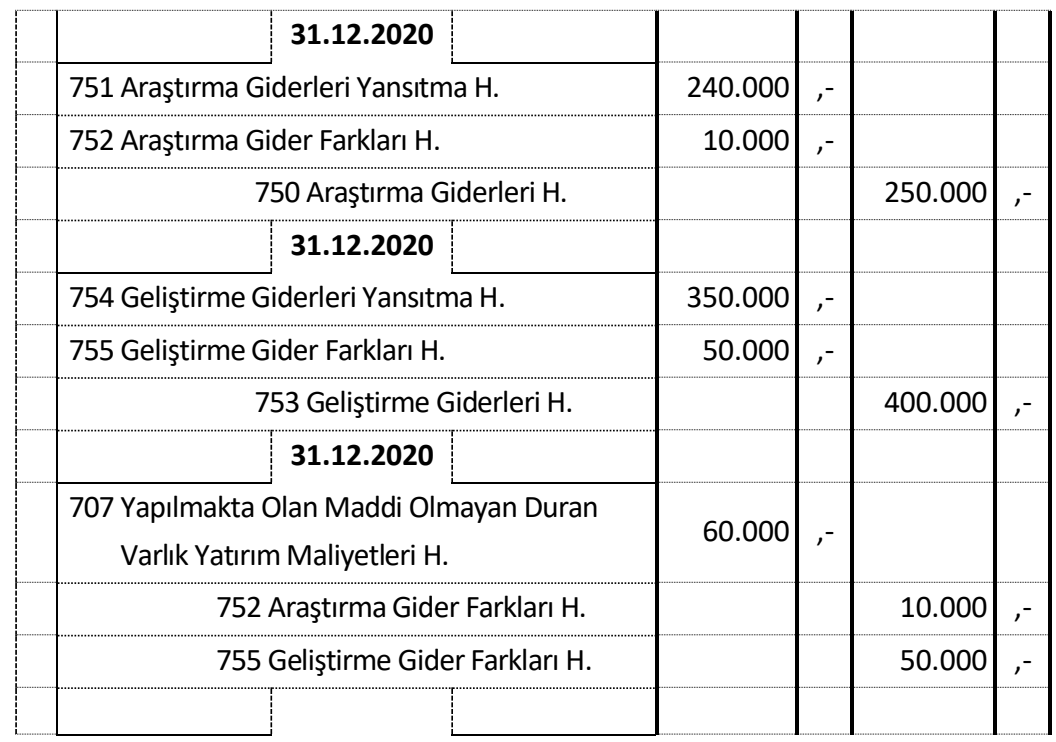

Yapılan bu kayıtla beraber dönem sonu itibariyle 707 Yapılmakta Olan Maddi Olmayan Duran Varlık Yatırım Hesabı'nda biriken toplam tutar, fiili olarak gerçekleşen araştırma ve geliştirme giderleri toplam tutarına eşitlenmiştir. Bu hesapta biriken 250.000,- TL tutarındaki araştırma gideri, dönem sonunda aktifleştirilebilir nitelikte olmadığından 630 Araştırma ve Geliştirme Giderleri Hesabı'na aktarılır. Buna karşılık, 400.000,- TL tutarındaki geliştirme gideri ise süreç sonunda aktifleştirilebilir nitelikte olduğundan 264 Geliştirme Giderleri Hesabı'na aktarılır.

\begin{tabular}{|c|c|c|c|c|c|}
\hline 31.12 .2020 & & & & \\
\hline 264 Geliştirme Giderleri H. & 400.000 &,- & & \\
\hline $\begin{array}{r}\text { 630 Araştırma ve Geliştirme Giderleri H. } \\
\text { 707 Yapılmakta Olan Maddi Olmayan } \\
\text { Duran Varlık Yatırım Maliyetleri } \mathrm{H} .\end{array}$ & & & & \\
\hline & & & & & \\
\hline
\end{tabular}

Geliştirme sürecinin sonunda maddi olmayan duran varlıklardan kullanıma hazır hale gelenlere ait tutarlar da 264 Geliştirme Maliyetleri Hesabı'ndan düşülerek 263 işletme İçinde Oluşturulmuş Maddi Olmayan Duran Varlıklar Hesabı'na aktarılacaktır.

\begin{tabular}{|c|c|c|c|c|}
\hline 31.12 .2020 & & & & \\
\hline $\begin{array}{l}\text { le Oluşturulmuş Maddi } \\
\text { ran Varlıklar H. }\end{array}$ & 400.000 & , & & \\
\hline 54 Geliştirme Maliyetleri H. & & & 400.000 &,- \\
\hline
\end{tabular}

Vergi etkisi açısından bakılacak olursa, bu örnekte 2020 yılı için yapılmış olan toplam ar-ge harcaması 650.000,- TL olarak gerçekleşmiştir. 5746 Sayılı Kanun kapsamında, bu işlemlerle ilgili beyannameye etki edecek gider toplamı 2020 yılı için 650.000,- TL / 5 yıl = 130.000,- TL'dir. Buna karşılık, TMS/TFRS esas alınarak yapılan kayıtlara göre 250.000,- TL'si araştırma gideri, 80.000,- $\mathrm{TL}^{\prime} \mathrm{si}^{3}$ ise geliştirme giderinin amortismanı olacak şekilde toplam 330.000,- TL'lik gider bu yılın matrahına etki etmektedir. Aradaki fark; 330.000 $130.000=200.000$, - TL'dir. Kısacası, mevzuata göre yapılacak kayıtlarda 200.000,- TL tutarındaki rakam gider olarak yazılamayacaktır. Bu fark kurumlar vergisi oranıyla çarpıldığında; $200.000 \times \% 20=40.000,-$ TL'lik bir geçici vergi farkının oluştuğu tespit edilmektedir. TMS/TFRS'ye göre yapılacak raporlamada oluşan 40.000,TL'lik indirilebilir geçici vergi farkı için de gerekli kayıtlar yapılmalıdır. 
b) Dönem sonunda fiili olarak gerçekleşen harcamanın araştırma faaliyetleri için 200.000 ,- TL ve geliştirme faaliyetleri için ise 320.000,- TL olarak gerçekleştiği tespit edilmiştir. Dolayısıyla dönem içinde gerçekleşen harcamalar nedeniyle ilgili varlık ve kaynak hesaplarına karşılık 750 Araştırma Giderleri Hesabı 200.000,- TL, 753 Geliştirme Giderleri Hesabı 320.000,- TL borçlandırılmıştır. Bu kapsamda 750 Araştırma Giderleri Hesabı ve 753 Geliştirme Giderleri Hesabı'nın dönem sonundaki görünümü aşağıdaki gibidir:
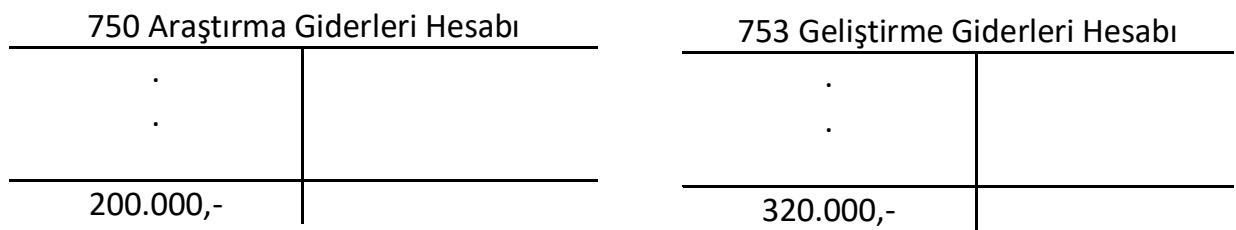

Dönem sonunda tespit edilen fiili rakam, dönem başında tahmin edilen rakamdan araştırma giderleri için 40.000,- TL, geliştirme giderleri için ise 30.000,- TL eksiktir. Bu kapsamda, araştırma ve geliştirme giderleri için olumlu bir farkla karşılaşılmıştır. Bu olumlu fark, 752 Araştırma Gider Farkları Hesabı ve 755 Geliştirme Gider Farkları Hesabı'nın alacağında izlenmektedir. Bu hesaplarda izlenen olumlu fark daha sonra 707 Yapılmakta Olan Maddi Olmayan Duran Varlık Yatırım Hesabı́nın alacağı karşıı̆ı̆ıda kapatılmalıdır. Bununla ilgili yapılması gereken kayıtlar aşağıdaki gibi olacaktır:

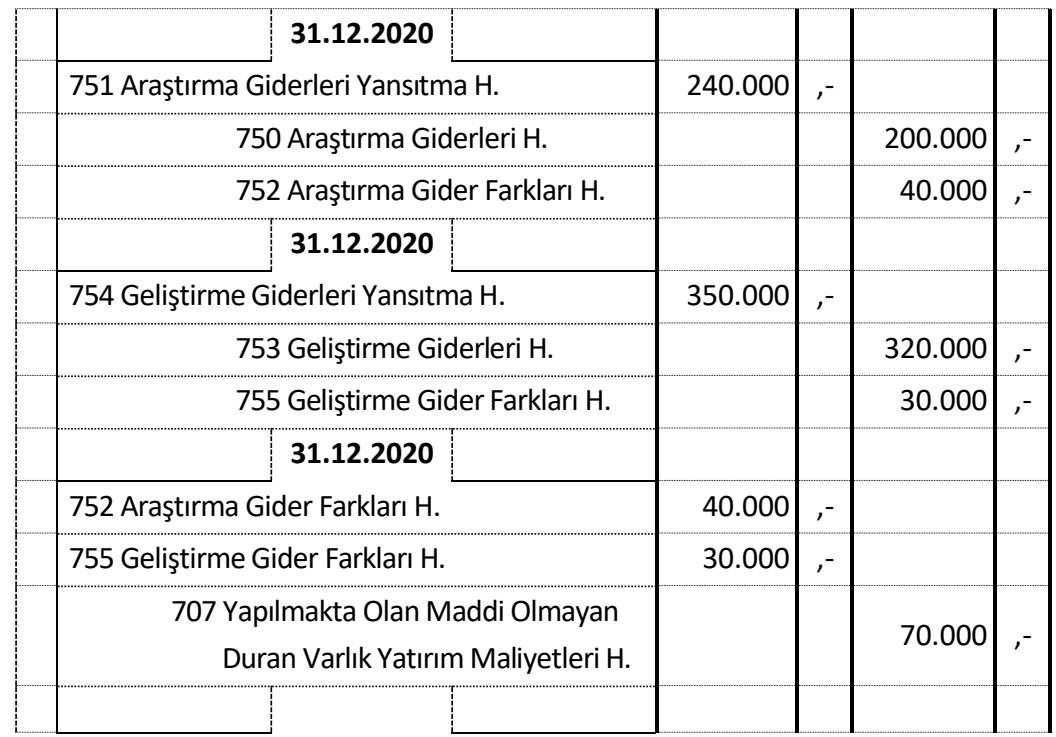

Yapılan bu kayıtla beraber dönem sonu itibariyle 707 Yapılmakta Olan Maddi Olmayan Duran Varlık Yatırım Hesabı'nda biriken/kalan toplam tutar, fiili olarak gerçekleşen araştırma giderleri ve geliştirme giderleri toplam tutarına eşitlenmiştir. Bu hesapta biriken/kalan 200.000,- TL tutarındaki araştırma gideri dönem sonunda aktifleştirilebilir nitelikte olmadığından 630 Araştırma ve Geliştirme Giderleri Hesabı'na aktarılır. Buna karşılık, 320.000,- TL tutarındaki geliştirme gideri ise dönem sonunda aktifleştirilebilir nitelikte olduğundan 264 Geliştirme Maliyetleri Hesabı'na aktarılır.

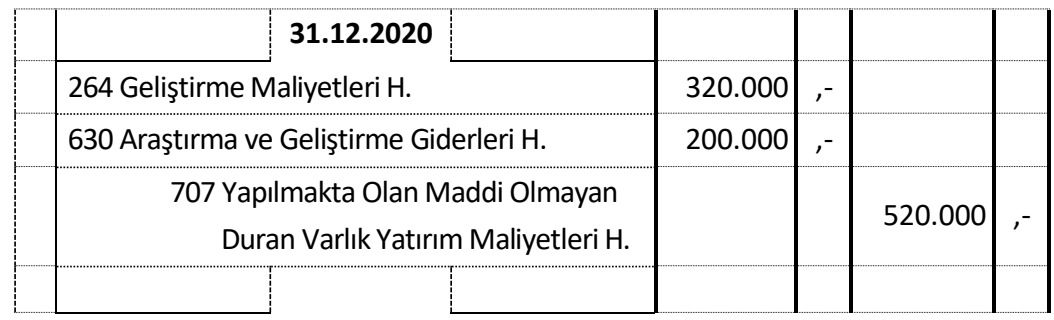


Geliştirme sürecinin sonunda maddi olmayan duran varlıklardan kullanıma hazır hale gelenlere ait tutarlar da 264 Geliştirme Maliyetleri Hesabı'ndan düşülerek 263 iş̧letme İçinde Oluşturulmuş Maddi Olmayan Duran Varlıklar Hesabı'na aktarılacaktır.

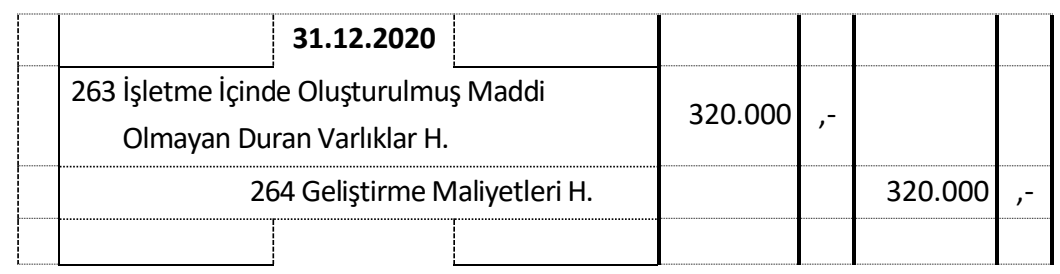

Yine vergi etkisi açısından değerlendirilirse, 5746 Sayılı Kanun kapsamında, bu işlemlerle ilgili beyannameye etki edecek gider toplamı 2020 yılı için 520.000,- TL / 5 yıl = 104.000,- TL'dir. Buna karşılık, TMS/TFRS esas alınarak yapılan kayıtlara göre 200.000,- TL'si araştırma gideri, 64.000,- $\mathrm{TL}^{\prime} \mathrm{si}^{4}$ ise geliştirme giderinin amortismanı olacak şekilde toplam 264.000,- TL'lik gider bu yılın matrahına etki etmektedir. Aradaki fark; $264.000-104.000=160.000,-$ TL'dir. Kısacası, mevzuata göre yapılacak kayıtlarda 160.000,- TL tutarındaki rakam gider olarak yazılamayacaktır. Bu fark kurumlar vergisi oranıyla çarpıldığında; $160.000 \mathrm{x}$ $\% 20=32.000$,- TL'lik bir geçici vergi farkının oluştuğu tespit edilmektedir. Bu kapsamda, standartlara göre yapılacak raporlamada oluşan 32.000,- TL'lik indirilebilir geçici vergi farkının da kayıtlara aktarılması gerekmektedir.

Şunu da ifade etmek gerekir ki, katlanılan patent masrafları da dâhil olmak üzere geliştirme sürecindeki aktifleştirilebilir toplam tutar, 263 İşletme İçinde Oluşturulmuş Maddi Olmayan Duran Varlıklar Hesabı'nda izlenecektir. Bu aşamadan sonra ise söz konusu maddi olmayan duran varlık için itfa süreci başlayacaktır.

TMS 38'e göre maddi olmayan duran varlıklar maliyet yöntemi veya yeniden değerleme yöntemlerinden biriyle değerlenmektedir. Her iki yöntemde de söz konusu varlığa ilişkin varsa, değer düşüklüğü zararı belirlenmektedir. Buradaki amaç, varlığın birikmiş itfa payları ve birikmiş değer düşüklüğü zararları düşüldükten sonraki değeri ile kayıtlarda yer almasını sağlamaktır (Md. 74-75). Bu kapsamda, yukarıda bilgileri yer alan ve 320.000,- TL olarak kayıtlara aktarılan maddi olmayan duran varlığın dönem sonundaki değerinin 300.000,- TL olarak hesaplandığı varsayılırsa ortaya çıkan değer düşüklüğü kadar karşılık ayrılması gerekir. Bununla ilgili yapılması gereken kayıt da aşağıdaki gibi olur:

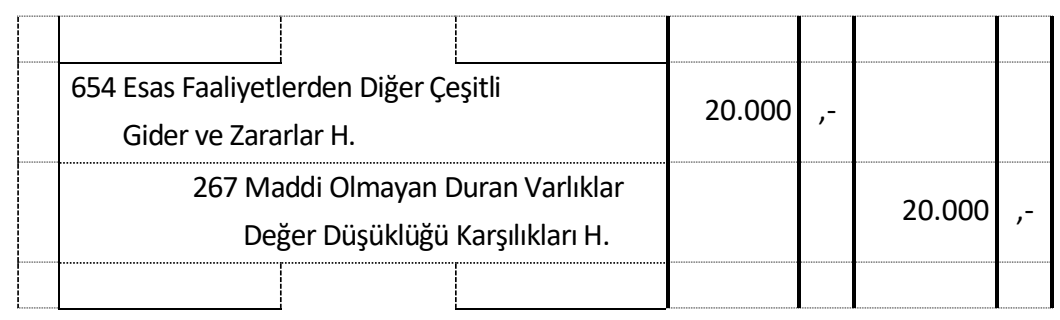

Bu kayıttan sonra söz konusu maddi olmayan duran varlık, birikmiş itfa payları ve birikmiş değer düşüklüğü zararları düşüldükten sonraki değeri ile finansal tablolarda yer alacaktır. TMS: $38^{\prime}$ de işletme içi oluşturulan maddi olmayan duran varlıklar için söz konusu varlıktan gelecekte elde edilecek ekonomik yararların değerlendirilmesinde TMS 36: Varlıklarda Değer Düşüklüğü Standardında yer alan ilkelerin kullanılması gerektiği belirtilmiştir (Md. 60).

\section{Sonuç ve Değerlendirme}

Varlık ve kaynak dengesinin unsurlarından biri olan maddi olmayan duran varlıklar, işletmeler açısından her geçen gün daha önemli hale gelmektedir. Açıklanan değerler yanında marka değeri, firma değeri gibi açıklanamayan değerlere de konu olan bu hesap grubu, yapılacak gerçeğe uygun hesaplamalarla işletmelerin gerçek performansını gösterebilme özelliğine de sahiptir. Gittikçe önemli hale gelen bu hesap grubunun raporlamasında sunum ve değerleme ön plana çıkmaktadır. 
Çalışmanın esas konusunu teşkil eden işletme içinde oluşturulan maddi olmayan duran varlıklar, araştırma ve geliştirme safhalarından oluşan bir dizi faaliyet sonucunda ortaya çıkmaktadır. TMS 38: Maddi Olmayan Duran Varlıklar Standardında belirlenen ilkelere göre, araştırma safhasındaki harcamaların gider olarak yazılması, geliştirme safhasındaki harcamaların ise aktifleştirilmesi gerekmektedir. Çalışmada, araştırma ve geliştirme safhalarındaki harcamalar kapsamında işletme içinde oluşturulan bir maddi olmayan duran varlığın oluşum sürecindeki muhasebe kayıtlarına değinilmiştir. Muhasebe kayıtlarında, Kamu Gözetimi, Muhasebe ve Denetim Standartları Kurumu tarafından yayımlanan Taslak Hesap Planı'ndaki hesaplardan yararlanılmıştır.

Fiili maliyet yönteminde işletme içinde oluşturulan maddi olmayan duran varlıklar için gerçekleşen fiili araştırma ve geliştirme harcamaları 750 Araştırma Giderleri Hesabı ve 753 Geliştirme Giderleri Hesabı'nda izlenmektedir. Bu hesaplara yazılan tutarlar daha sonra yansıtma hesaplara vasıtasıyla 707 Yapılmakta Olan Maddi Olmayan Duran Varlık Yatırım Maliyetleri Hesabı'nda toplanmaktadır. Bu hesapta toplanan araştırma giderleri 630 Araştırma ve Geliştirme Giderleri Hesabı'na, geliştirme giderleri ise aktifleştirilmek üzere 264 Geliştirme Maliyetleri Hesabı'na aktarılmaktadır. Geliştirme sürecinin sonunda maddi olmayan duran varlıklardan kullanıma hazır hale gelenlere ait tutarlar da 264 Geliştirme Maliyetleri Hesabı'ndan düşülerek 263 İşletme İçinde Oluşturulmuş Maddi Olmayan Duran Varlıklar Hesabı'na aktarılmaktadır.

Önceden saptanmış maliyet yöntemlerine göre işletme içinde oluşturulan maddi olmayan duran varlıklar için dönem başında tahmin edilen tutarlar yansıtma hesaplarına karşılık 707 Yapılmakta Olan Maddi Olmayan Duran Varlık Yatırım Maliyetleri Hesabı'nın borcuna yazılmaktadır. Dönem sonunda, gerçekleşen fiili rakamlarla tahmin edilen tutarlar karşılaştırılarak gider farkları hesabı yardımıyla 707 Yapılmakta Olan Maddi Olmayan Duran Varlık Yatırım Maliyetleri Hesabı'ndaki tutarlar fiili durumla eşit hale getirilmektedir. Burada dikkat edilmesi gereken husus, olumlu bir farkla karşılaşılması durumunda 752 Araştırma Gider Farkları Hesabı ile 755 Geliştirme Gider Farkları Hesabı'nın alacaklandırılması, olumsuz bir farkla karşılaşılması durumunda ise söz konusu hesapların borçlandırılması gerektiğidir. Fiili maliyet yönteminde olduğu gibi 707 Yapılmakta Olan Maddi Olmayan Duran Varlık Yatırım Maliyetleri Hesabı'nda biriken araştırma giderleri dönem sonunda 630 Araştırma ve Geliştirme Giderleri Hesabı'na, geliştirme giderleri ise 264 Geliştirme Maliyetleri Hesabı'na aktarılmaktadır. Yine geliştirme sürecinin sonunda kullanıma hazır hale gelen maddi olmayan duran varlıklara ait tutarlar bu hesaptan düşülerek 263 İşletme iç̧inde Oluşturulmuş Maddi Olmayan Duran Varlıklar Hesabı'nda izlenmektedir.

Hangi unsurların hangi hesaplarda izlenmesi gerektiği yanında konunun, mevcut uygulamalar ile TMS/TFRS uygulamaları açısından değerlendirilmesi finansal rapor kullanıcıları açısından önemdir. Zira 5746 Sayılı Araştırma, Geliştirme ve Tasarım Faaliyetlerinin Desteklenmesi Hakkında Kanun'da; AR-GE, yenilik ve tasarım harcamalarının 213 Sayılı Vergi Usul Kanunu'na göre aktifleştirilmek suretiyle amortisman yoluyla itfa edileceği belirtilmektedir (Md. 3/1). Muhasebeleştirme açısından önemli olan bu husus, mevcut uygulama ile standartlar arasında bir takım farklııklara neden olabilmektedir. Nitekim, 5746 Sayılı Kanun'a göre yapılan harcamaların araştırma ve geliştirme safhasına bakılmadan aktifleştirilmek suretiyle amortisman yoluyla itfa edileceği, buna karşılık TMS 38'e göre ise araştırma safhasındaki harcamaların gider olarak yazılacağı, geliştirme safhasındaki harcamaların da aktifleştirilebileceği öngörülmektedir. Bu farklıık, standartlar kapsamında kayıt yapılması halinde ortaya çıkacak vergi etkisinin hesaplanması ve raporlanmasını gerekli kılmaktadır.

Yine mevcut muhasebe uygulamaları ile TMS/TFRS açısından değerlendirildiğinde başarıyla sonuçlanmış AR-GE faaliyetleri sonucunda ortaya çıkan bir maddi olmayan duran varlığın itfası konusunda bir takım farklılıkların olduğu belirtilmelidir. Tekdüzen Hesap Planı'nda bu varlıkların ya 5 yıl içinde ya da yararlanma süresinin belli olması halinde bu süre içinde eşit taksitlerle itfa edileceği ifade edilmiştir. TMS 38 'de ise maddi olmayan duran varlıkların yararlı ömürleri dikkate alınmış, sınırlı ve sınırsız yararlı ömre göre sınıflandırma yapılmıştır. İtfa payının sadece sınırlı yararlı ömre sahip maddi olmayan duran varlıklar için hesaplanacağı, sınırsız yararlı ömre sahip olanlar için ise hesaplanmayacağı belirtilmiştir.

Çalışmanın kapsamındaki hesaplarla ilgili Taslak Hesap Planı'nda yer alan bazı eksiklik ve yanlışlıkların burada açıklanmasına gerek duyulduğu da belirtilmelidir. Bu kapsamda, Taslak Hesap Planında yer alan "753 
Geliştirme Giderleri Hesabı"nın işleyişi açıklanırken söz konusu hesabın dönem sonunda hangi hesaplarla karşılaştııılarak kapatılması gerektiği hususunda "754 Geliştirme Giderleri Yansıtma Hesabı"na yer verilmemiştir. "754 Geliştirme Giderleri Yansıtma Hesabı"yla ilgili yapılan açıklamanın ilk cümlesinde de "753 Geliştirme Giderleri Hesabı” yazılacağı yere yanlışlıkla "750 Araştırma Giderleri Hesabı” yazılmıştır. Bu eksiklik ve yanlışlıkların giderilmesi söz konusu hesap planının işlerliği açısından gerekli ve önemlidir.

\section{Beyan ve Açıklamalar (Disclosure Statements)}

1. Bu çalışmanın yazarı, araştırma ve yayın etiği ilkelerine uyduğunu kabul etmektedir (The author of this article confirms that her work complies with the principles of research and publication ethics).

2. Yazar tarafından herhangi bir çıkar çatışması beyan edilmemiştir (No potential conflict of interest was reported by the author).

3. Bu çalışma, intihal tarama programı kullanılarak intihal taramasından geçirilmiştir (This article was screened for potential plagiarism using a plagiarism screening program).

\section{Son Notlar}

1. Burada sadece 5746 Sayılı Kanun'da yer alan kayıt kuralları ile TMS 38'in kayıt ilkelerindeki farklılık nedeniyle ortaya çıkan vergi etkisi açıklanmış, vergi indirimi kapsam dışında tutulmuştur.

2. $200.000,-T L / 5$ yıl $=40.000,-T L / y ı l$. (Faydalı ömrün 5 yıl olduğu kabul edilmiştir.)

3. $400.000,-T L / 5$ yıl $=80.000,-T L / y ı l$. (Faydalı ömrün 5 yıl olduğu kabul edilmiştir.)

4. $320.000,-T L / 5$ yıl $=64.000,-T L / y ı l$. (Faydalı ömrün 5 yıl olduğu kabul edilmiştir.)

\section{Kaynaklar}

Bozdemir, E. (2018). Ar-Ge ve yenilik faaliyetlerinde teşviklerin muhasebe standartları açısından değerlendirilmesi ve muhasebeleştirilmesi. Mali Çözüm, Ocak-Şubat 2018, 13-40.

Brand Finance (2019). Global Intangible Finance Tracker (GIFT ${ }^{T M}$ ) - An annual review of the world's intangible value, November 2019.

Deran, A., Özulucan, A., \& Arslan, S. (2017). Araştırma ve geliştirme giderlerinin vergi mevzuatı, ar-ge ile ilgili yasal düzenlemeler: Tekdüzen Muhasebe Sistemi ve 38 No'lu Türkiye Muhasebe Standardına göre muhasebeleştirilmesi. işletme ve iktisat Çalışmaları Dergisi, 5(4), 27-43.

Fidancı, N. (2017). Araştırma - geliştirme (Ar-Ge) ve tasarım harcamalarının vergisel düzenlemeler ve teşvikler çerçevesinde incelenmesi ve muhasebeleştirilmesi. Muhasebe ve Vergi Uygulamaları Dergisi, 10(5), 69-90.

Finansal Raporlama Standartlarına Uygun Hesap Planı Taslağı, Kamu Gözetimi Muhasebe ve Denetim Standartları Kurumu.

https://www.kgk.gov.tr/Portalv2Uploads/files/Duyurular/v2/TFRS/EK2_Finansal\%20Raporlama\%20Standartlar \%C4\%B1na\%20Uygun\%20Hesap\%2OPlan\%C4\%B1\%20Tasla\%C4\%9F\%C4\%B1.pdf (Erişim Tarihi: 13.08.2019).

Şeker, S. (2009). Ar- ge harcamalarının muhasebesi ve indirimi. Vergi Sorunları Dergisi, 245, 31-39.

TMS 38: Maddi Olmayan Duran Varlıklar Standardı, Kamu Gözetimi Muhasebe ve Denetim Standartları Kurumu. https://www.kgk.gov.tr/Portalv2Uploads/files/Duyurular/v2/TMS/TMS_2020/TMS\%2038.pdf Erişim Tarihi: 24.08.2020).

5746 sayılı Araştırma, Geliştirme ve Tasarım Faaliyetlerinin Desteklenmesi Hakkında Kanun. https://www.mevzuat.gov.tr/MevzuatMetin/1.5.5746.pdf (Erişim Tarihi: 02.09.2020). 
This Page Intentionally Left Blank 